\title{
ELASTYCZNE FORMY ZATRUDNIENIA JAKO ELEMENT GOSPODAROWANIA KAPITAŁEM LUDZKIM
}

\section{WPROWADZENIE}

W obecnych czasach rynek pracy podlega głębokim i dynamicznym przemianom. Globalizacja, rozwój nauki oraz nowych technologii zmusza do poszukiwania rozwiązań, które zwiększałyby konkurencyjność podmiotów oraz pozwalałaby szybko reagować na zmieniające się wciąż wymagania otoczenia. Zasoby ludzkie przez długi czas postrzegane były głównie jako źródło kosztów, które należy zmniejszać, nie tracąc przy tym na wydajności pracy. Obecnie natomiast nikt nie ma już wątpliwości, że jednym ze źródeł przewagi konkurencyjnej może być kapitał ludzki oraz jego umiejętne wykorzystanie. Nowoczesne przedsiębiorstwo bowiem to nie tylko kapitał finansowy i rzeczowy, ale również wartości niematerialne. Kapitał ludzki jest w nim traktowany jako najcenniejsze aktywa, na które składają się zasób wiedzy, umiejętności, motywacji, doświadczeń, odpowiedzialności oraz zdolności intelektualnych tkwiących w ludziach ${ }^{1}$.

Początków myśli o kapitale ludzkim w teorii ekonomii należy upatrywać w osiemnasto- i dziewiętnastowiecznych pracach takich ekonomistów jak A. Smith, J.B. Say oraz J.S. Mill². Uważali oni, że człowiek posiada kapitał w postaci wiedzy, umiejętności i zdrowia. Im większy jest kapitał zgromadzony w jednostkach, tym więcej dóbr można wytworzyć, co przyczynia się do wzrostu bogactwa narodów. W drugiej połowie

* Doktorantka, Katedra Prawa Pracy, Wydział Prawa i Administracji, Uniwersytet Łódzki.

1 G. Wronkowska, Kapitał ludzki. Ujęcie teoretyczne, Wydawnictwo Uniwersytetu Ekonomicznego w Krakowie, Kraków 2012, s. 15.

2 A. Smith, Badania nad naturą i przyczynami bogactwa narodów, Wydawnictwo Naukowe PWN, Warszawa 1954; J.B. Say, Traktat o ekonomii politycznej, Wydawnictwo Naukowe PWN, Warszawa 1960; J.S. Mill, Zasady ekonomii politycznej, Wydawnictwo Naukowe PWN, Warszawa 1965. 
XX wieku powstała teoria kapitału ludzkiego, dostarczająca argumentów za tym, że człowiek to najbardziej wartościowy element w zasobach przedsiębiorstwa, gdyż jego wiedza i zdolności mają duży wpływ na wielkość i jakość produkcji oraz usług, a to pociąga za sobą wzrost gospodarczy ${ }^{3}$. W Polsce znaczący przełom w postrzeganiu kapitału ludzkiego nastąpił wraz z przemianami ustrojowymi oraz społeczno-gospodarczymi i towarzyszącą im potrzebą zwiększenia konkurencyjności na rynku.

Obecnie koncepcja gospodarowania kapitałem ludzkim kładzie nacisk na wartość zasobów pracy i ich optymalne wykorzystanie. Stara się pogodzić z jednej strony ekonomiczny punkt widzenia, zorientowany na wynik finansowy, a z drugiej mieć na względzie również rozwój i satysfakcję pracowników. Na gospodarowanie kapitałem ludzkim składają się działania podejmowane w obszarze związanym w występowaniem człowiek w organizacji, zapewniające jej liczebność i jakość. Celem tych działań jest jak najlepsze wykorzystanie potencjału pracy dla wzrostu efektywności i wartości organizacji ${ }^{4}$.

Współcześnie coraz częściej odchodzi się od tradycyjnego modelu zatrudnienia na rzecz elastycznych form, które umożliwiają lepsze i szybsze dostosowywanie się do zmian na rynku pracy. Coraz rzadziej można spotkać kariery zawodowe polegające na długotrwałym zatrudnieniu w jednym zakładzie pracy lub w tej samej branży. Bardzo ważna jest natomiast otwartość na przestrzenną dyslokację, krótkoterminowa elastyczność oraz zróżnicowany czas pracy. Okresy działalności zawodowej człowieka przeplatają się z okresami bezrobocia, a poszukiwanie pracy często łączy się z koniecznością ciągłego dokształcania się, a czasem nawet przekwalifikowania.

Powstaje w tym miejscu pytanie, jakie rozwiązania organizacyjne, prawne i społeczne można wprowadzić, żeby optymalnie wykorzystać kapitał ludzki. Z punktu widzenia prawa pracy, jedną z propozycji są niewątpliwie elastyczne (nietypowe) formy zatrudnienia. Umożliwiają one efektywne i świadome zarządzanie przedsiębiorstwem, stanowią narzędzie walki z bezrobociem, mogą być także pomocne w czasie kryzysu. Niniejsze opracowanie stanowi analizę powyższego pojęcia w kontekście gospodarowania kapitałem ludzkim. Autorka przedstawi również wybrane instytucje prawne zaliczane do elastycznych form zatrudnienia, kładąc nacisk na ukazanie zalet i wad każdej z nich, oraz odwoła się do coraz popularniejszej koncepcji flexicuirity.

\section{ZATRUDNIENIE TYPOWE I ATYPOWE (NIETYPOWE)}

Pracodawca, podejmując decyzję o zatrudnieniu, może wybierać spośród wielu rodzajów umów. Wybierając odpowiednią formę zatrudnienia, może lepiej reagować na zachodzące na rynku zmiany oraz optymalnie kształtować rozmiar zatrudnienia, a także organizację i czas pracy.

3 W. Jarecki, M. Kunasz, E. Mazur-Wierzbicka, P. Zwiech, Gospodarowanie kapitałem Iudzkim, Ekonomicus, Szczecin 2010, s. 17-18.

4 A. Sajkiewicz, Zasoby ludzkie w firmach, Poltext, Warszawa 2000, s. 18. 
Powstanie i rozwój nietypowych form zatrudnienia jest determinowane wieloma czynnikami. Po pierwsze, można wskazać na zmiany zatrudnienia w poszczególnych sektorach gospodarki, związane m.in. z odpływem ludności z rolnictwa do przemysłu, a ostatnimi czasy do sektora usług. Nierzadko o stosowaniu nietypowych form zatrudnienia decydują procesy technologiczne, wymuszające np. system zmianowy. Inną przesłanką jest dążenie pracodawców do ograniczenia kosztów związanych z zatrudnianiem pracowników. Na ekspansję nietypowych form zatrudnienia wpływają również uwarunkowania legislacyjne - nowelizacje kodeksu pracy oraz uchwalanie aktów prawnych regulujących nowe instytucje prawne ${ }^{5}$.

W literaturze przedmiotu można spotkać różne określenia: „nietypowe formy zatrudnienia”, ,atypowe formy zatrudnienia”, „nowe formy zatrudnienia” a także „elastyczne formy zatrudnienia"6. W pierwszej kolejności jednak konieczne jest zdefiniowanie, czym jest zatrudnienie typowe. Za typowy model zatrudnienia uznaje się stosunek pracy na podstawie umowy o pracę na czas nieokreślony, w pełnym wymiarze czasu pracy, według powszechnie obowiązujących norm pracy, charakteryzujący się ciągłością (w założeniu ma to być zatrudnienie długotrwałe) oraz wykonywaniem pracy pod kierownictwem pracodawcy, w ściśle określonym miejscu (najczęściej w siedzibie pracodawcy) oraz w stałych godzinach pracy ${ }^{7}$. W uzasadnieniu do uchwały z dnia 16 kwietnia 1998 r. (sygn. akt III ZP 52/97, OSNP 1998/19/558) Sąd Najwyższy stwierdzit, że „standardem prawa pracy jest zatrudnianie na podstawie umowy o pracę na czas nieokreślony, która ze względu na sposób i zakres ochrony przed jej rozwiązaniem najpełniej respektuje uzasadnione potrzeby pracownika".

W związku z tym, nietypowe formy zatrudnienia w szerokim znaczeniu obejmują wszelkie sposoby zatrudnienia odbiegające od modelu tradycyjnego, które nie posiadają jednej lub kilku z wyżej wymienionych cech. Będą to zatem również, obok zatrudnienia pracowniczego, umowy cywilnoprawne, samozatrudnienie czy też praca nakładcza. W wąskim ujęciu natomiast, na którym skupia się przedmiotowe opracowanie i które pokrywa się w pewnym stopniu z regulacjami wspólnotowymi, zatrudnienie nietypowe to zatrudnienie $w$ ramach stosunku pracy, obejmujące:

- pracę na podstawie umów terminowych,

- pracę w niepełnym wymiarze czasu pracy,

- telepracę,

- pracę tymczasową ${ }^{8}$.

Elastyczność zatrudnienia może także przejawiać się w stosowanych systemach i rozkładach czasu pracy, jest to jednak zagadnienie bardzo szerokie i wielo-

${ }^{5}$ E. Bąk, Nietypowe formy zatrudnienia na rynku pracy, Wydawnictwo C.H. Beck, Warszawa 2009, s. 12-13.

6 Ibidem, s. 9.

7 Tak m.in. A. Chobot, Nowe formy zatrudnienia. Kierunki rozwoju i nowelizacji, Wydawnictwo Naukowe PWN, Warszawa 1997, s. 130; E. Bąk, Nietypowe..., s. 15.

8 Z. Kubot, Szczególne formy zatrudnienia i samozatrudnienia, Wrocław 2000, s. 7. 
wątkowe, w związku z czym nie zostanie podjęte w niniejszym opracowaniu. W dalszej części natomiast zostaną omówione pozostałe elastyczne formy zatrudnienia w znaczeniu wąskim.

\section{PRACA NA PODSTAWIE TERMINOWYCH UMÓW O PRACE}

Jedną z najczęściej występujących w Polsce elastycznych form zatrudnienia są terminowe umowy o pracę. W obecnym stanie prawnym, zaliczyć do nich można, zgodnie z art. 25 k.p. ${ }^{9}$, umowę o pracę na czas określony, umowę o pracę na czas wykonania określonej pracy, umowę o pracę na czas zastępstwa innego pracownika w czasie jego usprawiedliwionej nieobecności w pracy oraz umowę o pracę na okres próbny, która może poprzedzać każdą z wymienionych wyżej umów. Cechą charakterystyczną tych umów jest ograniczenie ich trwania w czasie i konieczność oznaczenia terminu końcowego.

Elastyczność terminowych umów o pracę przejawia się w kilku obszarach, m.in. w sposobie ich ustania. Zgodnie z art. 30 § 1 pkt 4 k.p., umowa o pracę rozwiązuje się z upływem czasu, na jaki została zawarta. Umowa o pracę zawarta na okres próbny rozwiązuje się z upływem tego okresu (art. 30 § 2 k.p.). Oznacza to, że upływ czasu powoduje automatyczne rozwiązanie umowy (z wyjątkami wynikającymi z art. 177 k.p., który przewiduję ochronę pracownic w ciąży i na urlopie macierzyńskim) i nie ma potrzeby dokonywania dodatkowych czynności przez pracownika albo pracodawcę. Po drugie, stosunkowo łatwo można takie umowy wypowiedzieć. Umowa o pracę na czas określony, chociaż, co do zasady, powinna trwać przez czas, na jaki została zawarta, może być rozwiązana wcześniej z zachowaniem dwutygodniowego terminu wypowiedzenia, jeśli została zawarta na okres dłuższy niż 6 miesięcy i strony przewidziały w umowie możliwość jej wcześniejszego rozwiązania ${ }^{10}$. Umowa o pracę na okres próbny może być wypowiedziana z zachowaniem trzydniowego, tygodniowego albo dwutygodniowego okresu wypowiedzenia, w zależności od długości okresu próbnego, natomiast termin wypowiedzenia umowy o pracę na zastępstwo wynosi 3 dni robocze.

9 Ustawa z dnia 26 czerwca 1974 roku - Kodeks pracy, Dz.U. z 2014 roku, poz. 1502 z późn. zm.

10 Co więcej, zgodnie z art. 411 § 2 k.p., w razie ogłoszenia upadłości lub likwidacji pracodawcy, umowa o pracę zawarta na czas określony albo wykonania określonej pracy może być rozwiązana przez każdą ze stron za dwutygodniowym wypowiedzeniem. Podobną regulację można odnaleźć w art. 5 ust. 7 ustawy z dnia 13 marca 2003 r. o szczególnych zasadach rozwiązywania z pracownikami stosunków pracy z przyczyn niedotyczących pracowników, Dz.U. 2015.192 z dnia 9.02.2015 r. W razie wypowiadania pracownikom stosunków pracy w ramach grupowego zwolnienia, umowy o pracę zawarte na czas określony lub na czas wykonania określonej pracy mogą być rozwiązane przez każdą ze stron za dwutygodniowym wypowiedzeniem. 
W obowiązującym stanie prawnym brak również regulacji przewidujących dopuszczalny czas trwania umów o pracę na czas określony. Jedynym „wentylem bezpieczeństwa”, który ma zapobiegać nadużywaniu tej formy zatrudnienia jest art. $25^{1}$ k.p.

W tym miejscu należy odwołać się do założeń planowanej nowelizacji kodeksu pracy. Projekt ustawy wpłynął do Sejmu w dniu 10 kwietnia 2015 r. (druk nr 3321) i dotyczy zmian w zakresie terminowych umów o pracę, zmierzających do ograniczenia nieuzasadnionego wykorzystywania umów o pracę na czas określony. Prace nad zmianą przepisów podyktowane były wszczęciem przez Komisję Europejską w stosunku do Polski postępowania w sprawie niezgodności przepisów kodeksu z wymogami dyrektywy Rady 99/70/WE z dnia 28 czerwca 1999 r. ${ }^{11}$, a także orzecznictwem Trybunału Sprawiedliwości Unii Europejskiej ${ }^{12}$. Nowelizacja ustawy przewiduje m.in. ograniczenie katalogu umów o pracę i rezygnację z umowy na czas wykonania określonej pracy. Dookreślona również została specyfika umowy o pracę na okres próbny poprzez wskazanie, że zawiera się ją w celu sprawdzenia kwalifikacji pracownika i możliwości jego zatrudnienia do wykonywania pracy określonego rodzaju. Ponowne zawarcie umowy o pracę na okres próbny z tym samym pracownikiem jest możliwe, jeżeli pracownik ma być zatrudniony do wykonywania innego rodzaju pracy albo po upływie co najmniej 3 lat od ustania poprzedniego stosunku pracy, jeżeli pracownik ma być zatrudniony do wykonywania tego samego rodzaju pracy. Bardzo istotną zmianą jest wskazanie, że okres zatrudnienia na podstawie umowy o pracę na czas określony, a także łączny okres zatrudnienia na podstawie umów o pracę na czas określony zawieranych między tymi samymi stronami stosunku pracy, nie może przekraczać 33 miesięcy, a łączna liczba tych umów nie może przekraczać trzech. Ograniczenia te nie będą miały zastosowania, jeśli umowa zawarta jest $w$ celu zastępstwa

11 Dyrektywa dotycząca Porozumienia ramowego w sprawie pracy na czas określony, zawartego przez Europejską Unię Konfederacji Przemysłowych i Pracodawców (UNICE), Europejskie Centrum Przedsiębiorstw Publicznych (CEEP) oraz Europejską Konfederację Związków Zawodowych (ETUC), Dz.Urz. WE L 175 z 10.07.1999, s. 43; polskie wydanie specjalne: rozdz. 5, t. 3, s. 368.

Zarzuty Komisji Europejskiej w sprawie niezgodności przepisów Kodeksu pracy z wymogami dyrektywy dotyczą trzech obszarów: po pierwsze - krótszy okres wypowiedzenia umów zawieranych na czas określony obowiązujących przez długi czas w stosunku do długości okresu wypowiedzenia umów zawieranych na czas nieokreślony w przypadku umów obejmujących podobny okres oznacza mniej korzystne traktowanie pracowników zatrudnionych na czas określony bez obiektywnego uzasadnienia; po drugie - okres, który musi upłynąć między dwiema umowami na czas określony, aby nie były one uważane za „następujące po sobie”, jest zbyt krótki, po trzecie - pojęcie „zadań realizowanych cyklicznie", w ramach którego dozwolone jest nieograniczone zawieranie następujących po sobie umów na czas określony, nie jest wystarczająco określone prawem, aby można było zapobiegać zawieraniu nadmiernej liczby takich umów.

12 W szczególności chodzi tutaj o wyrok z dnia 13 marca 2014 r. w sprawie C-38/13 Nierodzik (pytanie Sądu Rejonowego w Białymstoku), w którym Trybunał uznał, co do zasady, za sprzeczne z dyrektywą kodeksowe rozwiązania dotyczące wypowiadania umów na czas określony.

Druk nr 3321, Strona internetowa Sejmu RP, www.orka.sejm.gov.pl/Druki7ka.nsf/0/47CA03D E61C1F035C1257E26004416C7/\%24File/3321.pdf [dostęp: 30.05.2015]. 
pracownika w czasie jego usprawiedliwionej nieobecności w pracy, wykonywania pracy o charakterze dorywczym lub sezonowym albo przez okres kadencji oraz gdy pracodawca wskaże obiektywne przyczyny leżące po jego stronie. Pracodawca jest wtedy zobowiązany zawiadomić właściwego okręgowego inspektora pracy o zawarciu takiej umowy wraz ze wskazaniem przyczyny. Ponadto, nowelizacja uzależnienia długość okresu wypowiedzenia umowy o pracę zawartej na czas określony od okresu zatrudnienia u danego pracodawcy, analogicznie jak w przypadku umowy o pracę zawartej na czas nieokreślony.

Dokonując oceny proponowanych zmian można śmiało stwierdzić, że ustawodawca ogranicza elastyczność powyższych form zatrudnienia na rzecz zwiększenia stabilności i bezpieczeństwa pracownika. Umowy o pracę na czas określony są bowiem często zawierane na długie okresy bez obiektywnego uzasadnienia. Tymczasem celem takiej umowy nie jest długotrwałe zatrudnianie pracowników, gdyż do tego służy umowa o pracę na czas nieokreślony. Można jednak wskazać na pewne mankamenty omawianej nowelizacji. Przede wszystkim, sformułowanie „obiektywne przyczyny leżące pod stronie pracodawcy", które uzasadniałyby zawarcie umowy na czas określony dłuższy niż dopuszczalny, jest sformułowaniem nieostrym i będzie stanowiło pole do nadużyć ze strony pracodawców. Obowiązek dokonania zgłoszenia okręgowemu inspektorowi pracy nie stanowi żadnego zabezpieczenia interesów pracownika - zgłoszenie ma jedynie charakter notyfikacyjny, gdyż Państwowa Inspekcja Pracy nie ma uprawnień do weryfikowania zasadności stosowania wyjątku. Poza tym, formułując definicję umowy o pracę na okres próbny, wzięto pod uwagę jedynie cel, w jakimi to pracodawca zawiera ją z pracownikiem, pominięto natomiast fakt, że umowa ta ma służyć również pracownikowi w celu sprawdzenia, czy odpowiadają mu warunki pracy i płacy.

\section{PRACA W NIEPEŁNYM WYMIARZE CZASU PRACY}

Jedną z najczęściej występujących w praktyce elastycznych form zatrudnienia jest zatrudnienie w niepełnym wymiarze czasu pracy. Przepisy prawa pracy nie zawierają definicji takiego typu zatrudnienia. Można jednak odwołać się z tym zakresie do dyrektywy Rady 97/81 z 1997 r., z której wynika, że pracownik zatrudniony w niepełnym wymiarze godzin to pracownik, którego normalna liczba godzin pracy, obliczona według średniej tygodniowej lub na podstawie średniej z okresu zatrudnienia wynoszącego maksymalnie jeden rok, jest mniejsza niż normalna liczba godzin pracy w przypadku porównywalnego pracownika zatrudnionego w pełnym wymiarze godzin. Zatem praca w niepełnym wymiarze czasu pracy to praca w wymiarze niższym niż pełny wymiar określony na podstawie art. 129 k.p. ${ }^{13}$ Strony stosunku pracy

13 U. Torbus, Rola elastycznych form zatrudnienia w godzeniu nauki z pracą zawodową, [w:] A. Bieliński, A. Giedrewicz-Niewińska, M. Szabłowska-Juckiewicz (red.), Elastyczne formy zatrudnienia i organizacji czasu pracy, Oficyna Wydawnicza ASPRA, Warszawa 2015, s. 263. 
mają dużą swobodę w określeniu wymiaru zatrudnienia niepełnoetatowego - rozkład i intensywność pracy w poszczególnych tygodniach może być różna, a dowolność ta determinowana jest głównie przyjętym okresem rozliczeniowym ${ }^{14}$.

Przepisy kodeksu pracy przewidują zasadę równego traktowania pracowników, niezależnie od tego, w jakim wymiarze czasu pracy są zatrudnieni. Stosownie do art. $29^{2} \S 1$ k.p., zatrudnienie na niepełnym etacie nie może powodować ustalenia warunków pracy i płacy pracownika w sposób mniej korzystny w stosunku do pracowników wykonujących taką samą lub podobną pracę w pełnym wymiarze czasu pracy, z uwzględnieniem jednak proporcjonalności wynagrodzenia za pracę i innych świadczeń związanych z pracą, do wymiaru czasu pracy pracownika. Zrozumiałe jest bowiem, że takiemu pracownikowi będzie przysługiwało proporcjonalnie niższe wynagrodzenie i mniejszy wymiar urlopu wypoczynkowego. Pracownicy zatrudnieni w niepełnym wymiarze czasu pracy objęci są także przepisami dotyczącymi nakazu równego traktowania i zakazu dyskryminacji.

Omawiana forma zatrudnienia pozwala na dostosowanie czasu pracy do indywidualnych potrzeb, zarówno pracodawców, jak i pracowników. Dla pierwszej grupy jest sposobem szybkiego reagowania na zmiany dokonujące się na rynku pracy, pracownikom natomiast pozwala łączyć aktywność zawodową z życiem rodzinnym (jest to forma bardzo popularna wśród rodziców wychowujących dzieci i osób opiekujących się innymi członkami rodziny), kształceniem, czy też funkcjami społecznymi. Zatrudnienie w niepełnym wymiarze czasu pracy znacznie ułatwia młodym ludziom wchodzenie na rynek pracy, starszym natomiast płynne przejście na emeryturę ${ }^{15}$.

Pomimo tych oczywistych zalet, zatrudnienie w takiej formie wiąże się z pewnymi niebezpieczeństwami. Należy zwrócić uwagę na art. 151 § k.p., regulujący pracę w godzinach nadliczbowych. Zgodnie z jego brzmieniem, strony powinny ustalić w umowie o pracę dopuszczalną liczbę godzin pracy ponad określony w umowie wymiar czasu pracy, których przekroczenie uprawnia pracownika, oprócz normalnego wynagrodzenia, do dodatku do wynagrodzenia za pracę w godzinach nadliczbowych. Godziny nadliczbowe dla tego typu pracownika, w braku odpowiedniej regulacji w umowie, będą zatem rozpoczynały się po przekroczeniu ośmiogodzinnej (lub wydłużonej) normy dobowej ${ }^{16}$, co w istocie powoduje przerzucenie na pracownika ryzyka gospodarczego pracodawcy ${ }^{17}$. Dodatkowo, jak podnosi się w literaturze, warunkiem korzystnego funkcjonowania pracy w niepełnym wymiarze czasu pracy jest jej dobrowolność, uzależniona od odpowiednio wysokiego poziomu dochodów, chroniącego przed wymuszoną wieloetatowością ${ }^{18}$.

14 Ibidem, s. 263.

15 E. Bąk, Nietypowe..., s. 41.

16 Wyrok SN z 9 sierpnia 1985 r., I PRN 64/85, OSNCP 1986, nr 5, poz. 79.

17 U. Torbus, Ochrona pracowników w elastycznych formach zatrudnienia jako warunek stabilizacji w stosunkach pracy, [w:] A .Bieliński, A. Giedrewicz-Niewińska, M. Szabłowska-Juckiewicz (red.), Elastyczne..., s. 62.

18 Ibidem, s. 62. 


\section{TELEPRACA}

Początki telepracy sięgają lat 60. XX wieku, kiedy to brytyjska firma The English FI Group wprowadziła program pracy zdalnej, umożliwiający pracę w domu dla kobiet pracujących przy usługach programistycznych ${ }^{19}$. Dekadę później, w czasach kryzysu paliwowego i wzrastającego zanieczyszczenia środowiska, amerykański naukowiec J.M. Nilles opracował koncepcję teledojazdów (telecommuting), która zakładała okresową pracę poza siedzibą firmy - telepracę (teleworking), rozumianą jako każdorazowe zastąpienie podróży związanych z pracą technologią informacyjną ${ }^{20}$.

Normatywna regulacja telepracy w prawie polskim pojawiła się w roku 2007, kiedy to weszła w życie ustawa nowelizująca kodeks pracy i wprowadzająca do niego omawianą instytucję ${ }^{21}$. Stosownie do art. $67^{5}$ k.p., telepraca to praca wykonywana regularnie poza zakładem pracy, z wykorzystaniem środków komunikacji elektronicznej w rozumieniu przepisów o świadczeniu usług drogą elektroniczną. Telepracownik natomiast to pracownik, który wykonuję pracę w warunkach określonych powyżej i przekazuje pracodawcy wyniki pracy, w szczególności za pośrednictwem środków komunikacji elektronicznej. Przyjęta w kodeksie pracy definicja telepracy oznacza, że nie musi być to jedynie praca wykonywana w domu, ale może to być również tzw. telepraca nomadyczna, wykonywana w miejscu, w jakim aktualnie pracownik się znajduje oraz telepraca świadczona w specjalnie do tego przystosowanych miejscach (telecentrach, telechatkach oraz telewioskach).

Telepraca jest formą wykonywania pracy korzystną zarówno dla pracodawcy, jak i pracownika. Po pierwsze, umożliwia pracodawcy znaczne ograniczenie kosztów związanych m.in. z wynajęciem powierzchni biurowej, miejsc parkingowych, opłaceniem mediów czy też zorganizowaniem przestrzeni socjalnej. Musi się on jedynie liczyć z koniecznością zakupu odpowiedniego sprzętu dla pracownika i zapewnieniem mu dostępu do środków komunikacji elektronicznej22. Pracodawca ma również większe możliwości rozwoju swojego przedsiębiorstwa i zwiększania miejsc pracy, nie musi bowiem zapewniać nowym pracownikom dodatkowej przestrzeni. Co więcej, pracownik będzie bardziej skłonny wykonywać pracę nawet w zamian za niższe wynagrodzenie, jeśli będzie mógł oszczędzić czas i koszty związane z codziennymi dojazdami do miejsca pracy. Telepraca pozwala również aktywizować pracowników mieszkających na obszarach wiejskich, gorzej rozwiniętych gospodarczo, oddalonych od dużych ośrodków miejskich, a także osoby niepełnosprawne. Z punktu widzenia pracownika, ta forma zatrudnienia umożliwia łatwiejsze pogodzenie obowiązków pra-

19 E. Stroińska, Elastyczne formy zatrudnienia. Telepraca. Zarządzanie pracą zdalną, Poltext, Warszawa 2012, s. 74.

20 J.M. Nilles, Telepraca. Strategie kierowania wirtualną załogą, WNT, Warszawa 2003, s. 21.

21 Ustawa z dnia 24 sierpnia 2007 r. o zmianie ustawy - Kodeks pracy oraz niektórych innych ustaw, Dz.U. 2007.181.1288 z dnia 1 października 2007 r.

22 Z. Olejniczak, Telepraca - nowa szansa na zatrudnienie, „Polityka Społeczna” 2000, nr 10, s. $17-21$. 
cowniczych z życiem osobistymi i rodzinnym, pozwalając jednocześnie pracodawcy na zoptymalizowanie pracy do potrzeb prowadzonego przedsiębiorstwa. Dodatkowo, zgodnie z przepisami kodeksu pracy, telepracownikowi przysługują takie uprawnienia pracownicze i socjalne, jak „zwykłemu” pracownikowi, a zmiana z pracy stacjonarnej na pracę zdalną nie może się dokonać bez jego zgody²3.

Pomimo wskazanych powyżej zalet, telepraca nie jest często wybieraną formą zatrudnienia. Przyczyny takiego stanu rzeczy są różnorakie. Można wskazać przede wszystkim na niemożność sprawowania przez pracodawcę rzeczywistej kontroli nad pracownikiem. Stosownie bowiem do art. $67^{14} \S 2$ k.p., jeżeli praca jest wykonywana w domu telepracownika, pracodawca ma prawo przeprowadzać kontrolę za uprzednią zgodą telepracownika wyrażoną na piśmie, albo za pomocą środków komunikacji elektronicznej, albo podobnych środków indywidualnego porozumiewania się na odległość i tylko w celach wymienionych enumeratywnie w powołanym przepisie. Co więcej, pracodawca jest zobowiązany realizować wobec telepracownika pracującego w domu, z pewnymi wyłączeniami, obowiązki związane z BHP w zakresie wynikającym z rodzaju i warunków wykonywanej pracy, co w praktyce nierzadko jest utrudnione. Duże odległości od siedziby pracodawcy mogą również generować problemy ze skutecznym zarządzaniem personelem oraz prowadzić do izolacji i braku rozwoju pracowników.

\section{PRACA TYMCZASOWA}

Praca tymczasowa została uregulowana w ustawie z dnia 9 lipca 2003 r. o zatrudnianiu pracowników tymczasowych ${ }^{24}$. Zgodnie z art. 1, ustawa reguluje zasady zatrudniania pracowników tymczasowych przez pracodawcę będącego agencją pracy tymczasowej oraz zasady kierowania tych pracowników i osób niebędących pracownikami agencji pracy tymczasowej do wykonywania pracy tymczasowej na rzecz pracodawcy użytkownika.

Jak wynika z literalnego brzmienia sformułowania „praca tymczasowa”, jest to zatrudnienie przejściowe, służące zaspokojeniu potrzeb o charakterze doraźnym, okresowym i sezonowym. Praca tymczasowa może być stosowana również w sytuacji, gdy terminowe wykonanie zadań przez pracowników zatrudnionych przez pracodawcę użytkownika nie byłoby możliwe lub gdy ich wykonanie należy do obowiązków nieobecnego pracownika zatrudnionego przez pracodawcę użytkownika. Pozwala ona zatem na czasowe zwiększenie zatrudnienia w celu umożliwienia niezakłóconego

23 A.M. Świątkowski, Telepraca - specyfika zatrudnienia na odległość, "Monitor Prawa Pracy” 2006, nr 7, s. 347-352.

24 Dz.U. 2003.166.1608 z dnia 22 września 2003 r. 
prowadzenia działalności ${ }^{25}$. Zapewnia również dostęp do bazy wykwalifikowanych pracowników, gotowych do szybkiego podjęcia pracy oraz optymalizację poziomu zatrudnienia w danym przedsiębiorstwie.

Pracownik tymczasowy to pracownik zatrudniony przez agencję pracy tymczasowej wyłącznie w celu wykonywania pracy tymczasowej na rzecz i pod kierownictwem pracodawcy użytkownika. Podstawą jego zatrudnienia może być umowa o pracę na czas określony lub umowa o pracę na czas wykonania określonej pracy. Z punktu widzenia pracownika, taka forma zatrudnienia zapewnia mu przede wszystkim szybkość znalezienia pracy oraz elastyczny rozkład czasu pracy. Praca tymczasowa może być dobrym rozwiązaniem m.in. dla uczniów lub studentów, którzy są dyspozycyjni jedynie w określone dni tygodnia lub w specyficznych godzinach oraz osób, które straciły pracę i szybko potrzebują nowej w celu zaspokojenia swoich podstawowych potrzeb. Niestety, tak duża elastyczność pociąga za sobą również dużą niestabilność zatrudnienia. Przejawia się ona m.in. w możliwości wcześniejszego rozwiązania umowy o pracę przez każdą ze stron za trzydniowym wypowiedzeniem, gdy została ona zawarta na okres nieprzekraczający 2 tygodni albo za jednotygodniowym wypowiedzeniem, gdy została zawarta na okres dłuższy niż 2 tygodnie. Co więcej, pracodawca użytkownik może zrezygnować z wykonywania pracy przez pracownika tymczasowego przed upływem uzgodnionego okresu wykonywania pracy tymczasowej i to bez konieczności podawania przyczyny. Niekorzystne dla pracownika jest również uregulowanie zawarte w art. 21 ustawy o pracownikach tymczasowych, zgodnie z którym do umów o pracę na czas określony zawartych między agencją pracy tymczasowej a pracownikiem tymczasowym nie stosuje się art. $25^{1}$ k.p., ograniczającego ponawianie umów o pracę na czas określony. Wyłączone zostało również stosowanie art. 177 § 3 k.p., przewidującego wydłużenie umowy do dnia porodu²6.

Omawiana forma zatrudnienia jest często nadużywana przez pracodawców użytkowników, a pracownicy wpadają w pułapkę trwałego wykonywania pracy tymczasowej. Ustawodawca, co prawda, w art. 20 ustawy wprowadza ograniczenia dotyczące okresu wykonywania pracy tymczasowej na rzecz jednego pracodawcy użytkownika, nie reguluje jednak przypadku korzystania na tym samym stanowisku z pracy innego pracownika zatrudnionego w tej samej agencji pracy tymczasowej lub tego samego pracownika tymczasowego, gdy zostanie on zatrudniony przez inną $\operatorname{agencję~}^{27}$. W konsekwencji zatem nie zostaje zachowany terminowy charakter zatrudnienia $w$ tej formie.

25 B. Wagner, Jednolitość, wielopostaciowość czy ewolucja funkcji ochronnej prawa pracy - zatrudnienie typowe versus tymczasowe, [w:] A. Sobczyk (red.), Z problematyki zatrudnienia tymczasowego, Oficyna a Wolters Kluwer business, Warszawa 2011, s. 65.

26 A. Sobczyk, Interesy pracodawcy i pracownika w zatrudnieniu tymczasowym, "Monitor Prawniczy" 2005, nr 11, s. 304.

27 U. Torbus, Ochrona..., s. 65. 


\section{PODSUMOWANIE}

Globalizacja oraz postęp naukowy i technologiczny pociąga za sobą konieczność poszukiwania czynników poprawiających konkurencyjność. W związku z tym, tradycyjny model zatrudnienia staje się mniej przydatny wobec niektórych kategorii pracowników, a rozwój elastycznych form zatrudnienia na rynku pracy jest nieunikniony. Dotyczy to zarówno instytucji omówionych w niniejszym opracowaniu, jak i pozapracowniczych form zatrudnienia. Jak to zostało wykazane, polskie prawo pracy daje wiele narzędzi umożliwiających dość elastyczne kształtowanie zatrudnienia i tworzenie nowych, mniej kosztownych miejsc pracy. Z drugiej jednak strony, można wskazać na wiele wad nietypowych form zatrudnienia, które kształtują sytuację pracownika w sposób niekorzystny. Elastyczność pociąga bowiem za sobą mniejszą stabilność zatrudnieni w nietypowych formach są narażeni na większe ryzyko utraty pracy oraz często nie posiadają tych samych uprawnień, co „zwykli” pracownicy. W związku z tym, należałoby szukać rozwiązań, które pozwoliłyby na pogodzenie elastyczności i bezpieczeństwa socjalnego.

W pewnym zakresie sposobem na zrównoważenie tych dwóch niezwykle istotnych wartości może być zaproponowana przez Unię Europejską koncepcja flexicurity. Termin ten pochodzi od połączenia dwóch angielskich słów: flexibility (elastyczność) oraz security(bezpieczeństwo). Jest to idea, która ma na celu zapewnienie bezpieczeństwa zatrudnienia na każdym etapie życia zawodowego, a jednocześnie stworzenie warunków dla ułatwiania rozwoju kariery zawodowej. Łączy w sobie aktywną politykę rynku pracy, elastyczne rozwiązania w zatrudnieniu, kształcenie przez całe życie przy jednoczesnym zapewnieniu bezpieczeństwa socjalnego 28 . Model zatrudnienia oparty na flexicurity zawiera zatem równoległe postulaty liberalizowania stosunków pracy oraz zapewnienia niezbędnej ochrony wszystkim podmiotom wykonującym pracę ${ }^{29}$. Instrumenty służące wdrażaniu tej koncepcji są związane nie tylko z tworzeniem nowych miejsc pracy, ale również ze zwiększeniem zdolności zatrudnienia po stronie pracowników i ich mobilności (employability), m.in. poprzez tworzenie programów szkoleń.

Obserwując rozwój nietypowych form zatrudnienia w Polsce można stwierdzić, że realizowana jest przede wszystkim idea flexibility i to w jej podstawowym znaczeniu, zapomina się natomiast o zapewnieniu pracownikom odpowiedniego bezpieczeństwa socjalnego. Jednakże planowane zmiany w zakresie terminowych umów o pracę są przykładem równoważenia elastyczności oraz bezpieczeństwa

28 L. Mitrus, Elastyczność zatrudnienia a stabilność socjalna, [w:] A.M. Świątkowski, Ochrona praw człowieka $w$ świetle przepisów prawa pracy i zabezpieczenia społecznego, Warszawa 2009, s. 193.

29 J. Wratny, Problemy ochrony pracowników w elastycznych formach zatrudnienia, „Praca i Zabezpieczenie Społeczne" 2007, nr 7, s. 2. 
zatrudnienia i stanowią ważny krok do tego, aby na polskim rynku pracy wdrażać również ideę security. Dzięki jej realizacji, zwiększona zostanie stabilizacja w stosunkach pracy.

\section{BIBLIOGRAFIA}

Bąk E., Nietypowe formy zatrudnienia na rynku pracy, Wydawnictwo C.H. Beck, Warszawa 2009.

Bieliński A., Giedrewicz-Niewińska A., Szabłowska-Juckiewicz M. (red.), Elastyczne formy zatrudnienia i organizacji czasu pracy, Oficyna Wydawnicza ASPRA, Warszawa 2015.

Bosak M. (red.), Funkcja ochronna prawa pracy a wyzwania wspótczesności, Warszawa 2014.

Chobot A., Nowe formy zatrudnienia. Kierunki rozwoju i nowelizacji, Wydawnictwo Naukowe PWN, Warszawa 1997.

Jarecki W., Kunasz M., Mazur-Wierzbicka E., Zwiech P., Gospodarowanie kapitałem Iudzkim, Economicus, Szczecin 2010.

Kubot Z., Szczególne formy zatrudnienia i samozatrudnienia, Wrocław 2000.

Mill J.S., Zasady ekonomii politycznej, Wydawnictwo Naukowe PWN, Warszawa 1965.

Nilles J.M., Telepraca. Strategie kierowania wirtualną załogą, WNT, Warszawa 2003.

Olejniczak Z., Telepraca - nowa szansa na zatrudnienie, „Polityka Społeczna” 2000, nr 10.

Sajkiewicz A., Zasoby ludzkie w firmach, Poltext, Warszawa 2000.

Say J.B., Traktat o ekonomii politycznej, Wydawnictwo Naukowe PWN, Warszawa 1960.

Smith A., Badania nad naturą i przyczynami bogactwa narodów, Wydawnictwo Naukowe PWN, Warszawa 1954.

Sobczyk A. (red.), Z problematyki zatrudnienia tymczasowego, Oficyna a Wolters Kluwer business, Warszawa 2011.

Sobczyk A., Interesy pracodawcy i pracownika w zatrudnieniu tymczasowym, „Monitor Prawniczy" 2005, nr 11.

Stroińska E., Elastyczne formy zatrudnienia. Telepraca. Zarządzanie pracą zdalną, Poltext, Warszawa 2012.

Świątkowski A.M., Ochrona praw człowieka w świetle przepisów prawa pracy i zabezpieczenia społecznego, Warszawa 2009.

Świątkowski A.M., Telepraca - specyfika zatrudnienia na odległość, "Monitor Prawa Pracy" 2006, nr 7.

Wratny J., Problemy ochrony pracowników w elastycznych formach zatrudnienia, „Praca i Zabezpieczenie Społeczne" 2007, nr 7.

Wronkowska G., Kapitał ludzki. Ujęcie teoretyczne, Wydawnictwo Uniwersytetu Ekonomicznego w Krakowie, Kraków 2012. 